\title{
Reason, Red in Tooth and Claw: Naturalising Enlightenment Thinking
}

\author{
Konrad Talmont-Kaminski \\ Marie Curie-Sklodowska University
}

\section{INTRODUCTION}

The Enlightenment raised reason to be the main human virtue. 1 However, the picture it had of reason was not borne out by time and investigation: the twentieth century has seen a growing cynicism concerning Enlightenment values, leading to various forms of antiintellectualism, be it nihilist or fundamentalist. To a great degree, much the same process can be seen to have taken place in philosophy:

After Popper, through Kuhn, Feyerabend, and all the others, the appeal to decisions by the scientific community widens rapidly-so rapidly that all of these latter have been accused of abandoning reason. Why? Only because of the tacit assumption that what cannot be reduced to logical method is nonrational. But this consequence is instead better taken as a reductio of this conception of rationality.

(Hooker 1995, 27-28)

It is in this context that naturalism can make its most valuable contribution. It does so by accepting that the traditional view of rationality is bankrupt but, instead of abandoning Enlightenment ideals, shows how they can be salvaged around the basis of a naturalised rationality. This naturalised rationality is understood in the context of our biological, evolutionary inheritance and, lacking the hubris of the traditional view, offers not the guarantee of perfection but the possibility of progress. In doing so, however, it avoids the objections which brought down the traditional view while still remaining robust enough to provide reason to think that we can transcend our existing limitations. As such, it offers a viable humanist response to the anti-intellectualisms of nihilism and fundamentalism. 


\section{NATURALISM WITHIN THE ENLIGHTENMENT TRADITION}

The twentieth century has been witness to an on-going onslaught upon the Enlightenment tradition. This has been the case both upon the grand stage of world events-rocked as they were time and again by factions espousing value systems antithetical to Enlightenment thinking-and the smaller stage of intellectual history, upon which the Enlightenment virtue of reason has been under attack from a number of directions. Naturalism, in the form it takes upon this smaller stage, can be usefully understood as the attempt to salvage what can be saved from the traditional Enlightenment values following the critiques they faced throughout the twentieth century.

Pascal, famously, spoke of humans as thinking reeds (Pascal 1669, pensée 347)—weak in flesh but magnificent in mind. For Pascal, just like for the other Enlightenment thinkers such as Voltaire, Diderot, Rousseau and Montesquieu, reason was the one human trait that allowed us to transcend our limitations, the one human trait that made progress a salve for the human condition. In their view of human reason, the Enlightenment thinkers showed more than just a slight tendency towards dualism-with reason belonging to some sphere largely independent of the reed-like human bodies. This view was understandable both historically and conceptually. Understandable historically; because Pascal and the others, despite the many differences between them and Descartes, to a great degree followed in Descartes' dualist footsteps and, partly through him, were steeped in the profoundly dualist Christian intellectual tradition. Understandable conceptually; since it was hard to see how reason could provide a way of transcending human frailties if it were intimately engaged with them.

By the beginning of the twentieth century, Enlightenment reason came to be understood as embodied in science and logic — these two being seen as the engines of human progress and as responsible for the great changes that took place in human well-being and capabilities in the previous century. Infamously, those engines carried us to the fields of Passchendaele, the ovens of Treblinka and the skies above Hiroshimaleading to a growing cynicism regarding the virtue of reason and science (Horkheimer and Adorno 1947). On the intellectual scene, the early- 
twentieth-century inheritors of the Enlightenment French were, foremost among others, the Viennese logical positivists. They, with their generally socially progressive ideals, were among the first to suffer due to the darkening character of European politics in the inter-war period and were forced to flee, primarily to America. There, their views were highly influential but also came under gradually more corrosive versions of criticism that ranged from the logical positivists' own awareness of the limitations of their project to espousals of a total rejection of their ideal of reason expressed by Rorty and many others that could be broadly characterised as postmodernists. Some of positivism's most extreme critics see positivism and fascist ideologies as part and parcel, the actual historical relation between those views being something of an embarrassing difficulty for that 'discourse' - as is the actual intellectual genealogy of recent anti-Enlightenment philosophies, reaching back as it does to the profascist literati of the 1930s (Wolin 2004).

Of course, neither the Viennese nor the other philosophers who saw themselves as carrying on the Enlightenment tradition were of one voice on any of a number of issues. Still, both they and their critics saw the strength or weakness of reason as turning on its intimate relationship with logic; whose sovereignty was the only guarantee that reason could be free of the baser aspects of our nature.

Brown (1988) characterises this logic-based view of rationality as having three features:

(1) Rational solutions should be universal.

(2) Rationally acceptable conclusions must follow with necessity from the information given.

(3) The rationality of the conclusions is determined by whether they conform to the appropriate rules. (after Hooker 1991, 44f.)

The view is an understandably attractive one. On the one hand, all three features may be thought to be realistic so long as the rules of rational reasoning could be simply read off logical relations. On the other hand, the form of reason characterised by them appears to offer us the opportunity to escape the contingencies of human foibles. Together, the view makes 
concrete the way to achieve the transcendence the Enlightenment thinkers dreamed of.

One of the attempts to arrive at a model of such rationality took the form of the search for an inductive logic (Keynes 1921, Carnap 1950). For all the efforts that have been put into the search, however, Hume's problem remains as intransigent as ever. Yet, at the same time, the ampliative inferences we have continued to make-without a basis in any satisfactory theoretical understanding of induction-have continued to succeed at a rate that, in light of the problem of induction, must look miraculous.

Hooker (1991) recognises that much of the criticism raised against the traditional conception of reason, which depended to a great degree upon the sovereignty of logic, was apposite. The long litany of critiques that have dogged logic-based accounts of rationality over the major part of the twentieth century (Popper 1935, Goodman 1955, Quine 1960, Kuhn 1962, Feyerabend 1975 and many others) together with the failure to answer Hume's original problem has done grievous damage to the notion of a universal, logically necessary, rule-governed rationality. While some philosophers try to forge such a logicist account regardless, many feel compelled by the failure to reject Enlightenment ideals and to accept some sort of epistemic nihilism. Hooker, as well as many other naturalists, would seek something like a middle path between those two options:

I accept that Feyerabend is essentially correct in his insistence that the Western project for reason, as it is encapsulated along the rationalism-empiricism axis, is in serious difficulty and requires some superseding conception or other. But while Feyerabend's response has been to question, in an increasingly radical way, the transcendence project which it theorizes I shall argue that there is an alternative: accept the transcendence project and re-theorize the nature of reason and the life of reason. (Hooker 1991, 44)

This, then, is the naturalist position I wish to espouse-to continue with the Enlightenment project while rejecting the traditional view of rationality. This rejection goes much deeper than the particularities of the logicist view of reason that was constructed in the early twentieth century, however: the claim being made is that the Enlightenment's weakness was that it did not go far enough in its humanism by failing to bring reason down to the human level. In retaining the Cartesian view of reason as something semi- 
divine, Enlightenment thinking was guilty of hubris (not in the face of the gods but of nature, and of human nature in particular). With the gift of hindsight, the fall was inevitable. Given such a diagnosis, naturalism must do more than just replace the logicist view of reason with another account that claims for it unpossessed virtues. The foremost among them have to be claims of certainty that, as the Enlightenment's critics have been right to point out, have provided a rationalisation for the stifling of discussion after a 'rational' conclusion was reached. Of course, the sort of universal fallibilism that results from recognising our incapacity to achieve certainty is something that goes back to Peirce's (1868a, 1868b) critique of Descartes and has, thankfully, come to be generally accepted today both within and outside of naturalist circles. Still, for their fallibilism to be more than scepticism and to be able to continue with the transcendence project, the naturalists need to say something more positive about reason.

\section{A PLETHORA OF NATURALISMS}

Since Dewey's (1925) espousal of naturalism, a richly branching family of various positions that go by that name has evolved. Indeed, when one considers all these positions it is hard to identify anything that they have in common beyond a generally favourable attitude to science. At times, in fact, nothing more seems requisite for a view to be deemed naturalistic. Just how wide the scope is can perhaps be gauged when it is considered that Frank Jackson's (1997) defence of conceptual analysis is often considered a good example of naturalism, even while Millikan (2005) and Bishop and Trout (2005) see a robustly critical attitude to conceptual analysis as essential to naturalism. A term is only as useful as the class of things it identifies and, in the case of 'naturalism', the breadth of the common meaning is such as to have made it difficult to have a focussed discussion as anything like a core of the position has been obscured by vagueness. A case study of the difficulties this has caused is provided by the critical articles collected by De Caro and Macarthur (2004), which all too often end up being aimed at nothing more than some vague scientism.

Characterising naturalism as the rejection of logic-based accounts of reason together with a retention of Enlightenment ideals still leaves naturalism a broad church, but it helps to focus the debate around a clear 
position. Doing so, however, entails taking sides in naturalism's internecine struggles, particularly that over the question whether naturalism is to be primarily characterised in terms of its methodological or metaphysical claims. The distinction may be drawn (see, for example, Audi 1995, 517-518 or Knowles 2003) as follows:

Metaphysical naturalism takes as its starting point the assertion that only certain (naturalist) metaphysical claims are acceptable and that other (supernatural) claims are to be rejected. Most often the underlying metaphysical distinction is made on the basis of the ontology used by science by claiming that only entities recognised by science should be called upon by naturalist philosophy.

Methodological naturalism, on the other hand, has as its starting point the assertion that only certain kinds of epistemic methods can be rational. Again, it is typically - though not necessarily_science that provides the measure for what methods are acceptable. The relevant alternative is provided by the a priori/a posteriori distinction, with aposteriorist methodological naturalism claiming that most or all rational epistemic methods are only justifiable a posteriori (for example Haack 1993, 118ff).

To avoid a possible confusion it is important to note that the distinction between a metaphysical and a methodological naturalism appears also in a different context (for example in Plantinga 1996), in which that particular "methodological naturalism" is merely a weaker version of the metaphysical position in so far as the scientific ontology is accepted by it as just a working hypothesis. The specific context in which that distinction was originally made (possibly by De Vries 1986) is that of the intellectually bankrupt propagandising of the supposed virtues of various pseudo-scientific transmogrifications of creationism. The overall confused state of creationism's defenders can be seen in how that distinction is doubly defective: both because it distinguishes not between kinds of naturalist views but how they are held and because-given the general fallibilism of both science and naturalism-naturalist views can only ever be held as working hypotheses, rendering "metaphysical naturalism" an obviously self-contradictory straw man and leaving the so-called "methodological naturalism" the only live alternative. I will say no more of that distinction. 
The naturalist position I see Hooker taking (1997, 52), and the one I would argue for, is strong aposteriorist methodological naturalism, i.e. the view that all epistemic methods can at best be provided with a posteriori justifications only. In effect, first philosophy is abandoned and epistemic methods are recognised to be context-dependent, theory-laden and, of course, fallible both in their justification and their application. By prioritising the methodology over the metaphysics, this approach to naturalism to a large degree forestalls the questions of reductionism that plague metaphysical naturalism. By claiming that epistemic methods can only be justified a posteriori, this form of naturalism picks a middle path between the traditional position and a scientistic naturalism that would claim that science is the sole source of rational epistemic methods. The rejection of the traditional position that at least some epistemic methods are justified a priori seems to be necessitated by the failure of more than two-hundred-years-worth of attempts to find a solution to Hume's problem. Further support for this view can be seen to come from Quine's (1951) refutation of empiricist dogmas, the relevant implications having been pursued by Putnam (1976). On the other hand, the scientistic position seems to be not just insufficiently motivated but, more importantly, to run counter to what science tells us about the continuum of epistemic methods (Campbell 1974) that runs from the simple chemotaxis of single-celled organisms such as the paramecium, through such everyday uses of perception as looking both ways before you cross the road, to the evergrowing family of highly specific methods used (and tested) in science. Of course, Hooker and I are hardly the only supporters of the naturalist position under review (Haack 1993 and Rescher 1977 provide just two possible additional examples) and much work has already been done to motivate this methodological version of naturalism.

The move to give up on first philosophy brings both riches and troubles. The troubles come in the form of the knowledge provided by the science and whatever other effective epistemic methods humanity uses, which, given the rejection of a method foundationalism-or foundationalism as Haack $(1993,186)$ refers to it—naturalists are free to engage in coming to understand what methods are rational. The troubles are primarily those which affect any non-foundationalist position; particularly, the issue of justification that has already been raised. The naturalist must hope that 
their riches are sufficient to buy their way out of trouble. I will consider both in turn.

\section{THE RICHNESS OF NATURALISM}

Naturalism is, by its very nature, interdisciplinary. It does not have any a priori qualms about the relevance of how we reason to the question of how we should reason. As such, it can draw upon the lessons provided by the history of science as well as the sociology of science, much in the way that Kuhn (1962) suggested it. A historicised and sociologised philosophy of science has been a major step forward, however naturalism goes further. At the same time as it accepts the data from studies of scientific practice, it also learns from how living beings in general manage to deal with their environment, requiring it to draw upon the work of biologists and neuroscientists as well as that of other scientists. In effect, the sciences provide not only a useful case study for naturalised philosophy but are also valuable partners in the enterprise of seeking to understand how knowledge is actually obtained and used in the world, be it by humans or by their evolutionary predecessors. The approach that has been pursued for decades now by a number of evolutionary epistemologists (Campbell 1974, Plotkin 1982, Callebaut and Pinxten 1987) is just one example of this kind of interdisciplinarity. All of these disciplines provide a great wealth of knowledge about what reasoning and its evolutionary precursors are actually like.

Naturalised approaches to reasoning are also interdisciplinary in another respect. By considering reason in the concrete context of actual reasoning beings rather than as an abstract set of rules and relations, naturalism forces together epistemology and philosophy of mind, making it necessary to consider in close connection to each other such things as epistemic methods, rational decisions and other aspects of philosophy of mind. The result of the bringing together of what had seemed like disparate philosophical and scientific disciplines has been the embodied, situated cognitive science that has come of age during the last decade of the previous century and which is being developed by Andy Clark (1996), Dan Dennett (1997), David Chalmers (1996), Mark Bickhard and Loren Terveen (1995) and Shaun Gallagher (2005) among many others. Clark's 
work provides a good example of this kind of thoroughly naturalised and unashamedly multidisciplinary approach. Thus, his analysis of the role played by perception moves beyond philosophical standards that assumed the construction of a complete and neutral model of the environment, and instead learns from neurological and other empirical studies that perception is highly constructive and closely tied to action, giving us access, at the right time, to information which is adequate and in the appropriate form to make the decisions that need to be made at that very point. Such a focus on practical commitment is one that can be seen to run through naturalism.

At this point it might seem that the tag of scientism is one that well fits naturalism, given that it is various scientific disciplines that have been repeatedly called upon. To see why this is not a fair accusation it is necessary to consider further the relationship between science and naturalised philosophy of the type I argue for. The heart of the matter is the fact that the definition of this naturalism is to be found not in the acceptance of scientific methods, however they were to be demarcated, but in the rejection of the possibility of having any a priori justification for epistemic methods. Given the rejection of the a priori, in so far as any methods are to be favoured, such status can only be given on the basis of the observed results of applying those methods, be they "scientific" or otherwise. This means that, in so far as naturalism views science favourably, it does so only a posteriori-having seen that scientific methods do seem to provide an effective way to come to know the world we live in. Exactly the same is true for non-scientific methods, be they everyday practices people apply when crossing the street or choosing fruit at a grocer's, or be the activity under consideration literature or poetry, both of which I would argue have a cognitive, epistemic role. Given that naturalism does not see science as a set of universal methods, scientific activity can be seen as continuous with other human activities, different only in the degree of institutionalisation, formalisation, self-criticism, and self-awareness regarding the particular context-dependent methods it uses.

Considering the richly intertwined continuum of evolutionary developments in the means used to observe the environment that science reveals, any scientism that seeks to sharply distinguish between scientific methods and other means living beings use to make their way in the world is not just false but unscientific. Thus, the continuum of human methods 
must be seen as part of the continuum of the methods used by living beings in general. As such, human science, human knowledge and-perhaps most importantly-human reason must likewise be seen as part of that continuum. The precise path this continuum follows can be traced both in terms of the kinds of distinctions organisms are capable of making-from the identification of the slope of a sugar gradient made by a paramecium, through the human ability to identify someone they know merely by hearing their footsteps, to the detection of a subatomic particle in a particle accelerator - as well as in terms of the kinds of models organisms use to organise their knowledge-from the models pragmatically implicit in the reactions of that paramecium, through the explicit understanding people have of their surrounds, to the purely mathematical models used when dealing with the counterintuitive nature of the quantum world. One detailed discussion of just how these various abilities build upon each other is provided by Bickhard (2003) in his examination of how this process is tied to the emergence of reference, which is normally seen as a distinguishing mark of real cognition.

\section{THE TROUBLES NATURALISM FACES}

Naturalism's openness to various methods also has its downside. By accepting the input of other disciplines and epistemic methods, naturalist accounts of reason are forced to somehow deal with the fact that these various sources often proscribe differing courses of action. This is as true when comparing clinical medicine with homeopathy, or people's fast and frugal heuristics (Gigerenzer 2000) with Bayesian rules of inference, as when the comparison is between how a chemist and a paramecium would locate concentrations of dissolved sugars. An uncritical pluralism regarding methods is quite misplaced here. To use Peirce's (1877) phrase, "real and living doubt" will have real consequences in terms of the sorts of ways one will act and, although in discussion we may eschew commitment, we cannot avoid it in action. At the same time uncritical conventionalism, though quite capable of guiding actions, will not be capable of improving upon the status quo. In effect, the naturalist must find a way between conventions and anarchy. 
Invoking Peirce in this context is most appropriate, as a number of prominent naturalists who have grappled with these issues (Haack 1993, Hooker 1991, Hacking 1983, Hookway 2000, Rescher 2005) have found his pragmatism to be capable of providing the right framework for working towards an answer. Already we have seen something of Peirce's view in the synechist refusal to draw sharp distinctions between science and other epistemic methods. In this instance, however, the vital aspect of Peirce's thought is his (1878) insistence that "the whole function of thought is to produce habits of action". Hooker presents the point this way:

[A] shift to an alternative paradigm of acceptance as an act of practical commitment leads to a decision theoretic epistemology where consequences play a key role, acceptance strategies can be subject to selective development, and there is no requirement for foundations. (Hooker 1991, 63)

The approach offers the hope that it is possible to get away from a foundational model, in this case supposedly built up on a bedrock of a priori methods, without giving up on the transcendence project, as it is now the practical commitment which is to underwrite the necessary normativity. The question of normativity is vital for naturalism if the so-called naturalistic fallacy (Moore 1903) is to be shown to be no fallacy at all. That is, indeed, the aim of the neo-Peircean, biologically inspired project to develop a naturalist account of function that is pursued by Hooker, Bickhard (2003) and John Collier (2000) among others (and which is actually quite different from that pursued by Millikan (1984); who is also influenced by Peirce and biology, of course). In fact, given failure to provide a robust basis for normativity in anything other than the brute facts of our embodied selves being situated in our environment may, I would argue, lead to the conclusion that the actual fallacy was an anti-naturalist one. At the same time, it is important to note naturalist arguments to the effect that normativity is not actually needed, a recent influential argument to that effect having been put forward by Jonathan Knowles (2003).

Basing our understanding of methodology on a posteriori methods allows us to dull the edge of the objections that dealt the killing stroke to the traditional view. Treating the epistemic methods we use as open to development in much the same way as our beliefs about the world we live in (i.e. thinking that methods are essentially beliefs about how we go on 
about finding out about our world) provides a way to internalise Kuhn's and other's objections to the logic-based account of rationality. This, immediately, gives a strategy to dealing with Hume - that strategy being to deal how to live with his objection rather than trying to show it to have been somehow mistaken. Counter to Hume's seeming assumption, rationality turns out to be situated not in some universal method but in something like the humble habits that he, himself, fell back upon. There can be no guarantees that our methods will not fail us the next time we apply them. Yet, given the brute fact of our own (fragile) existence and the unavoidability of action, we are forced to chose on the basis of what understanding we hope we do possess. The sceptic has nothing to offer us in our need since, if we accepted their advice, we should have no basis to make any of the decisions that are forced upon us. Thankfully, Hume does not show that our methods will always fail in all possible worlds, but, rather, shows than there are no methods that will work across all of them. In its modesty, naturalism acknowledges this inevitability and only claims to seek methods that will be adequate in certain limited contexts. This response seems, in fact, to be very much in line with the kind of naturalism that Kemp Smith (1905a, 1905b) originally and H.O. Mounce (1999) recently see as lying behind Hume's arguments and his own not-sosceptical responses.

\section{NATURALIST'S TRANSCENDENCE}

At this point we are in the position to try and draw up a characterisation of the kind of naturalised rationality that the account I pursue leads to. Thinking back to Brown's (1988) characterisation of logic-based rationality we can juxtapose to it the features a naturalised rationality has:

(1) Rational solutions (or, more appropriately, methods) need not be universal, but only have to be effective in the appropriate limited contexts.

(2) Rationally acceptable conclusions (of psychological inferential processes) do not have to follow necessarily from the information given, as acceptance is not to be understood 
in terms of a formal relationship between propositions but in terms of a practical commitment.

(3) The rationality of the conclusions (of psychological inferential processes) is not necessarily determined by whether they conform to the appropriate rules, indeed the primary focus is removed from the conclusions and placed upon the actions that are taken on the basis of the practical acceptance of beliefs and methods that are all subject to further criticism and development.

This vision of rationality fits into the evolutionary synthesis (Huxley 1942) that first united various elements of biology and which is now bringing together an ever broader range of sciences. As such, it is a world away from the traditional Enlightenment view of rationality as a spark of something close to divinity trapped within brute beasts. Given that, and given the kind of limitations the new view of rationality places upon it, what prospect for transcendence can remain?

One of the core ideas within the evolutionary synthesis is that of emergence: the emergence of life out of inanimate matter, the emergence of complex life-forms from single celled organisms and, in our case, the emergence of rationality out of the simple forms of goal-seeking behaviour. Without going into the controversial details of emergence it still ought to be clear how significant that concept is to naturalism's metaphysical aspects, providing as it does scope for explaining the existence of mental entities without calling for either eliminative reductionism or dualism. Emergence is significant in another way-it shows how transcendence may lead to something which is totally new. This obviates the need for reference to some pre-existing standard or goal, marking the underlying notion of progress as one that is moving us away from ignorance and parochialism rather than towards omniscience and universality. Thus, the kind of transcendence that a naturalist can see rationality providing is one that stepwise moves us beyond our existing limitations and thereby reveals further limitations to be transcended. As such, reason becomes not just the engine of progress but also one of its main products, and science is not thought of as contrary to our biological inheritance but as emergent from it. Transcendence, on this picture, is 
achieved through the sometimes inventive and sometimes methodical application of our limited abilities, context-dependent methods and imperfect knowledge to augment our abilities, extend the reach of our methods and to add to our knowledge, all without ever negating the underlying boundedness of reason. This means that being rational entails neither being safe from human frailties nor not in need to further improvement. Still, the value of the kind of transcendence that a naturalist can offer lies simply in allowing us to do more things than we were able to previously and, at the same time, to understand our situation better than we were before, all the while making clear that we can never rest on our laurels. And that this is a worthwhile viewpoint can be seen all the more starkly against the background of the nihilisms of the last century as well as of the fanaticisms of the current century's opening years.

\section{REFERENCES}

Audi, R. (ed.) 1995: The Cambridge Dictionary of Philosophy. Cambridge: Cambridge University Press.

Bickhard, M. and Loren T. 1995: Foundational Issues in Artificial Intelligence and Cognitive Science: Impasse and Solution. New York: Elsevier Scientific.

Bickhard, M. 2003: "Process and Emergence: Normative Function and Representation." In: J. Seibt (ed.) Process Theories: Crossdisciplinary Studies in Dynamic Categories. Dordrecht: Kluwer Academic, 121-156.

Bishop, M. and Trout, J. D. 2005: Epistemology and the Psychology of Human Judgment. New York: Oxford University Press.

Callebaut, W. and Rik P. (eds.) 1987: Evolutionary Epistemology: A Multiparadigm Program With a Complete Evolutionary Epistemology Bibliography. Dordrecht: Reidel (Synthese Library 190).

Campbell, D. T. 1974: "Evolutionary Epistemology." In: P. A. Schilpp (ed.) The philosophy of Karl R. Popper. LaSalle, IL: Open Court, 412-463.

Carnap, R. 1950: Logical Foundations of Probability. Chicago: University of Chicago Press. 
Chalmers, D. 1996: The Conscious Mind. Oxford: Oxford University Press.

Clark, A. 1996: Being There. Cambridge, MA: MIT Press.

Collier, J. 2000: "Autonomy and Process Closure as the Basis for Functionality." In: Chandler, J. L. R. and van de Vijver, G. (eds.) Closure: Emergent Organizations and their Dynamics, 280-291.

De Caro, M. and Macarthur, D. (eds.) 2004: Naturalism in Question. Cambridge, MA: Harvard University Press.

Dennett, D. 1997. Kinds of Minds: Towards an Understanding of Consciousness. New York: Basic Books.

Dewey, J. 1925: Experience and Nature. Chicago: Open Court.

Feyerabend, P. 1975: Against Method. London: New Left Books.

Gallagher, S. 2005: How the Body Shapes the Mind. Oxford: Oxford University Press.

Gigerenzer, G. 2000: Adaptive Thinking. New York: Oxford University Press.

Goodson, N. 1955: Fact, Fiction, and Forecast. Cambridge, MA: Harvard University Press.

Haack, S. 1993: Evidence and Inquiry. Oxford: Blackwell.

Hacking, I. 1983: Representing and Intervening. Cambridge: Cambridge University Press.

Hooker, C. 1991: "Between formalism and anarchism." In: Munévar, G. (ed.) Beyond Reason. Dordrecht: Kluver Academic.

Hooker, C. 1995: Reason, Regulation, and Realism. Albany, NY: State University of New York Press.

Horkheimer, M. and Adorno, T. 1947: Dialektik der Aufklärung. Amsterdam: Querido Verlag.

Hookway, C. 2000: Truth, Rationality and Pragmatism. Oxford: Oxford University Press.

Hume, D. 1739/2000: A Treatise of Human Nature. Edited by Norton, D. F. and Norton, M. J.. Oxford: Oxford University Press.

Huxley, J. 1942: Evolution: The Modern Synthesis. London: George Allen and Unwin.

Jackson, F. 1997: From Metaphysics to Ethics. Oxford: Claredon Press. Kemp Smith, N. 1905a: "The Naturalism of Hume I." Mind 14, 149-173. Kemp Smith, N. 1905b: “The Naturalism of Hume II." Mind 14, 335-347. 
Keynes, J. M. 1921: Treatise on Probability. London: Macmillan \& Co. Knowles, J. 2003: Norms, Naturalism and Epistemology: The Case for Science without Norms. London: Palgrave Macmillan.

Kuhn, T. 1962: The Structure of Scientific Revolutions. Chicago: University of Chicago Press.

Millikan, R. G. 1984: Language, Thought, and Other Biological Categories. Cambridge, MA: MIT Press.

Millikan, R. G. 2005: Language: A Biological Model. Oxford: Oxford University Press.

Moore, G. E. 1903: Principia Ethica. Cambridge: Cambridge University Press.

Mounce, H. O. 1999: Hume's Naturalism. London: Routledge.

Pascal, B. 1669/1962: Pensées. Edited by Lafuma, L. Paris: Les Libraires Associés.

Peirce, C. S. 1868a: "Questions Concerning Certain Faculties Claimed for Man." Journal of Speculative Philosophy 2, 103-114.

Peirce, C. S. 1868b: "Some Consequences of Four Incapacities." Journal of Speculative Philosophy 2, 140-157.

Peirce, C. S. 1877: “The Fixation of Belief." Popular Science Monthly 12, November 1877, 1-15.

Peirce, C. S. 1878: "How to Make Our Ideas Clear." Popular Science Monthly 12, January 1878, 286-302.

Plantinga, A. 1996: “Methodological naturalism?” In van der Meer, J. (ed.) Facets of Faith and Science. Lanham, MA: University Press of America, 177-221.

Plotkin, H. C. (ed.) 1982: Learning, Development, and Culture: Essays in Evolutionary Epistemology. New York: John Wiley \& Sons.

Popper, K. 1935: Logik der Forschung. Vienna: Julius Springer.

Putnam, H 1976: “Two Dogmas' Revisited.” In: G. Ryle (ed.)

Contemporary Aspects of Philosophy. London: Oriel Press, 202-213.

Quine, W. V. O. 1951: "Two dogmas of empiricism." Philosophical Review 60, 20-43.

Quine, W. V. O. 1960: Word and Object. Cambridge, MA: MIT Press.

Rescher, N. 1977: Methodological Pragmatism. New York: New York University Press. 
Rescher, N. 2005: Reason and Reality. Lanham, MD: Rowman \& Littlefield.

Vries, P. de 1986: "Naturalism in the natural sciences." Christian Scholar's Review 15, 388-396.

Wolin, R. 2004: The Seduction of Unreason: The Intellectual Romance with Fascism from Nietzsche to Postmodernism. Princeton, NJ: Princeton University Press. 
